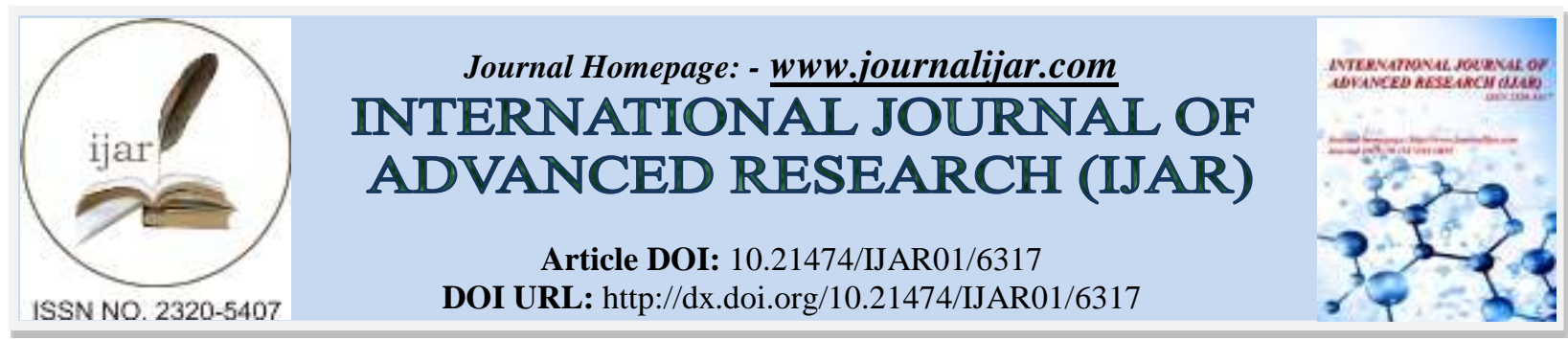

RESEARCH ARTICLE

\title{
THE IMPACT OF CONSUMER TRUST, PERCEIVED RISK, PERCEIVED BENEFIT ON PURCHASE INTENTION AND PURCHASE DECISION.
}

Widarto Rachbini.

Universitas Pancasila.

\section{Manuscript Info}

Manuscript History

Received: 15 November 2017

Final Accepted: 17 December 2017

Published: January 2018

Key words:-

Internet Consumer, Consumer Trust,

Perceived Risk, Perceived Benefit,

Purchase Intention, Purchase Decision.

\begin{abstract}
Indonesian Internet Service Providers Association (APJII) revealed that the number of Indonesian internet users in 2016 reached 132.7 million from a total population of 256.2 million. The number of smartphone users in the country in the same period reached 63.1 million. The development of communication and information technology provides a significant changes or influence on the growth and development of startup companies, especially in e-commerce industry in Indonesia. This study aims to reveal the relationship and influence of Consumer Trust on Perceived Risk and Purchase Intention, the impact of Perceived Benefit on Purchase Intention, as well as the influence of Purchase Intention on Purchase Decision. The results of the study show that Internet consumers trust, perceived risk, and perceived benefit have strong impacts on their purchasing intention and decisions. This research was analyzed by using Structural Equation modeling (SEM). The number of respondents in this study amounted to 200 respondents who aim to represent the number of existing population.
\end{abstract}

Copy Right, IJAR, 2018,. All rights reserved.

\section{Introduction:-}

Today the number of internet growth in Indonesia is very significant. The development of the digital world in Indonesia can be seen from the increasing number of internet users in 2016 which touches the number of 132.7 million or about $51.5 \%$ of the total population of Indonesia. The majority of internet users in this country is in Java Island with a total of 86 million users or about $65 \%$ of the total Internet users (APJII, 2016). Basically, Indonesia has a strong foundation in facing the challenges of the digital world in the future, and it can be a challenge or a threat, the following table, summarized the foundation of digital economy in Indonesia based on Idea's presentation in 2017 (Association of Indonesian E-commerce), among others as follows:

Table 1:- The foundation of Digital Economy in Indonesia (In Mio)

\begin{tabular}{|c|c|c|}
\hline No. & Description & Year 2017 \\
\hline 1 & Total Population & 262 \\
\hline 2 & Internet Users & 132.7 \\
\hline 3 & Social Media Users & 106 \\
\hline 4 & Mobile Subscription & 371.4 \\
\hline 5 & Number of Mobile Users & 92 \\
\hline
\end{tabular}

Source: Idea, (2017) 
In line with the table above which indicates that the internet users in Indonesia have more than 100 million, and related to the previous description, the Indonesian Internet Service Providers Association (APJII) also revealed that the behavior of internet users in Indonesia majority access internet via mobile phone. More details the table below outlines the percentage $(\%)$ and total number of internet users in Indonesia based on their behavior when accessing the internet, among others, are as follows:

Table 2:- Internet User Behavior in Indonesia

\begin{tabular}{|c|c|c|c|}
\hline \multirow[t]{2}{*}{ No. } & \multirow[t]{2}{*}{ Description } & \multicolumn{2}{|c|}{ Internet Users } \\
\hline & & In Mio & In \% \\
\hline 1 & Mobile Phone & 63.1 & 47.6 \\
\hline 2 & Mobile Phone \& Personal Computer & 67.2 & 50.7 \\
\hline 3 & Personal Computer & 2.2 & 1.7 \\
\hline 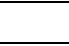 & Total & 132.7 & $100 \%$ \\
\hline
\end{tabular}

Source: APJII, (2016)

The data in the table above shows how the habit / behavior of Indonesian people in accessing internet, dominated by mobile phone users, that is equal to 63.1 million or equal to $47.6 \%$. Furthermore, according to Idea, (2017) the Association of Indonesian Ecommerce revealed that Indonesians people spend no less than $55 \%$ of their time accessing the internet. Idea also explains that the Indonesian people spend for 106 minutes a day using mobile phones, 80 minutes of watching TV, 59 minutes in front of the laptop, and the rest of each 28 minutes and 24 minutes spent listening to the radio and reading magazines or newspapers.

According to the Forrester report, (2008) Business to Consumer (B2C) Internet commerce enjoys a steady growth rate (about $19 \%$ per year), and it is a familiar mode of shopping for many consumers. Reports from various sources noted that in 2017, the e-commerce industry in Indonesia is predicted to be valued at $\$ 9.3$ billion, the rather large potential is in line with the development of general and niche e-commerce services in Indonesia (Jakarta Post, 2017). E-commerce and Fintech compete as the most-invested segment, with $21 \%$ and $20 \%$ respectively (Dailysocial, 2016). Here are 15 Biggest Startup Company (including e-commerce sectors) in Indonesia in 2017, among others, as follows:

Table 3:- 15 Biggest Startup Company In Indonesia.

\begin{tabular}{|c|c|c|}
\hline Company & Description & Rank \\
\hline Tokopedia & Buy/Sell Online - Safe and Comfortable & 1 \\
\hline Bukalapak & Easy And Trusted e-commerce & 2 \\
\hline Blibli & Online retailer, Anywhere, Anytime Shopping. & 3 \\
\hline Traveloka & Online Shopping Site - Cheap, Safe, Trusted & 5 \\
\hline Blanja.com & Indonesia's largest online fashion website & 6 \\
\hline Zalora Indonesia & Bolalob - Futsal - Football & 7 \\
\hline Bolalob & Online Shopping Paradise & 8 \\
\hline Elevenia & The number 1 healthcare website in Indonesia & 9 \\
\hline Alodokter.com & the Biggest Indonesia Bitcoin Exchange that act as backbone for the entire & 10 \\
\hline Bitcoin Indonesia & An Ojek For Every Need - GO-JEK is your personal time saver. & 11 \\
\hline Gojek & Zenius Education is an Education Company that produces multimedia & 12 \\
\hline Zenius Education & learning for Indonesian schoolkids & 13 \\
\hline Uzone Indonesia & Place to Share Something WOW & 14 \\
\hline Pulsk & Now Traveling is Easy -Hotel \& Flight Booking \\
\hline PegiPegi & 15 & \\
\hline
\end{tabular}

Source: Startupranking, (2017)

Referring to the table above, it shows that the top five companies / startup in Indonesia is in e-commerce industry. This supports some of the data presented in the previous description. 
Many scholars have argued that trust is a prerequisite for successful commerce because consumers are hesitant to make purchases unless they trust the seller (Gefen, 2002; Urban et, al., 2000). Consumer trust may be even more important in electronic, "cyber" transactions than it is in traditional, "real world" transactions. This is because of some of the characteristics of Internet cyber transactions, they are blind, borderless, can occur 24 hours a day and 7 days a week, and are non-instantaneous (payment may occur days or weeks before delivery is completed) can cause consumers to be concerned that the seller won't adhere to its transactional obligations. Consequently, trust in an Internet business is focused much more on transaction processes (Kim et, al., 2004), in contrast to that of traditional transactions involving brick-and-mortar stores where trust tends to be focused on face-to-face personal relationships. Quite possibly, the key to success in Internet business is the establishment of trusted transaction processes where esellers create an environment in which a prospective consumer can be relaxed and confident about any prospective transactions (Grabosky, 2001). Since trust is likely to play an essential role in online transactions, it is important to identify the antecedents of a consumer's trust in the context of an Internet transaction (Kim et, al., 2007).

In prior research, trust has been viewed through diverse disciplinary lenses and filters: economic (Dasgupta, 1990), social or institutional (Canzaroli, 1999), behavioural or psychological (Dirks and Ferrin, 2001), managerial or organizational (Balasubramanian et, al., 2003), and technological (Castelfranchi, 1999). Trust is considered essential in exchange relations because it is a key element of social capital (Mayer et, al., 1995) and is related to firm performance, satisfaction, competitive advantage, and other economic outcomes such as transaction cost (Balasubramanian et, al., 2003) and search cost reductions (Gulati, 1995).

Some recent studies (Gefen et, al., 2000; Kim et, al., 2005; Pavlou and Fygenson, 2006) have focused on the social and behavioral elements of trust in an e-commerce context, however these were again narrowly focused (e.g., they focused on a limited number of trust antecedents, or focused on trust in the community of sellers as a group), and therefore researchers have not yet developed a comprehensive understanding of the factors that predict consumer trust in the e-commerce context. Given the increasing prevalence of B to C Internet commerce, there is an urgent need to analyze an online consumer's decision making process from a holistic standpoint which can provide an understanding of the complex and dynamic phenomena of trust in online exchanges (Kim et, al., 2007). Kim et, al., (2007) develops a holistic trust based consumer decision model to describe the decision making process that a consumer uses when making a purchase from a given site. Their research revealed that by using Structural Equation Modeling technique (SEM), it provides empirical evidence that trust, perceived risk, and perceived benefit are strong determinants of a consumer's e-commerce transaction decision.

\section{Literature Review:}

Trust. Mayer et, al., (1995) defined trust as a behavioral one person based on his or her beliefs about the characteristics of another person. Plank et, al., (1999) recognized that consumer trust could have multiple referents such as salesperson, product, and company, and accordingly defined trust as a global belief on the part of the buyer that the salesperson, product, and company will fulfill their obligations as understood by the buyer. Similarly, in the e-commerce context (Whinston and Zhang, 2003; Beatty et, al., 1996; Urban et, al., 2000; McKnight and Chervany, 2002), some researchers have tended to define describe trust as a subjective belief, a subjective probability, the willingness of an individual to be vulnerable, reliance on parties other than oneself, or a person's expectation. An online consumer's trust is defined as a consumer's subjective belief that the selling party or entity will fulfill its transactional obligations as the consumer understands them (Kim et, al., 2007).

Consumer Trust / Trust and Perceived Risk. Past research has recognized that electronic purchase decisions are inherently risky, and therefore trust may be an important factor in giving consumers the confidence they need to engage in such transactions (Whinston and Zhang, 2003). Scholars have provided different views regarding the relationship between trust and risk, i.e. whether trust is an antecedent of risk, the same as risk, or a by product of risk. It is common to treat trust and risk as different concepts (Blau, 1964; Coleman, 1990; Williamson, 1993). Mayer et, al., (1995) proposed a model of dyadic trust in organizational relationships that includes characteristics of both the trustor and trustee that influence the formation of trust. The three characteristics included in the model to represent the perceived trustworthiness of the trustee are ability, benevolence, and integrity. The logic of this model is that if the trustor perceives a trustee's ability, benevolence, and integrity to be sufficient, the trustor will develop trust (an intention to accept vulnerability) toward the trustee. If the level of trust in a vendor surpasses a threshold of perceived risk, then the trustor will engage in a risky relationship with the vendor. In other words, trust is a key determinant of action in a situation in which there is perceived risk of a negative outcome (Luhmann, 1988). 
Trust is relevant in situations where one must enter into risks but has incomplete control over the outcome (Ratnasingam, 1998; Rousseau, 1998). Gambetta (1988) revealed that trust is particularly relevant in conditions of ignorance or uncertainty with respect to the unknown or unknowable actions of others. Due to the inherent nature of Internet shopping, consumers will always experience some level of risk. In essence, they make bets about the uncertainty of the future and the free actions of others (potentially trustworthy Web vendors, hackers, and unknown new technologies) (Kim et, al., 2007). In these uncertain situations, when consumers have to act, trust comes into play as a solution for the specific problems of risk (Luhmann, 1988). Therefore, as trust increases, consumers are likely to perceive less risk than if trust were absent, consumers are likely to perceive less risk than if trust were absent, the effect of trust is mediated by risk on the consumer's intention to purchase (Kim et, al., 2007).

Consumer Trust / Trust and Purchase Intention. The effect of trust is mediated by risk on the consumer's intention to purchase (Kim et, al., 2007). Several trust researchers have shown a direct relationship between trust and willingness to buy online from Internet vendors (Bhattacherjee, 2002; McKnight et, al., 1998). Kim et, al., (2007) added trust as critical variable in electronic commerce and also stated that the consumer will be more likely to engage in an internet purchase when trust is high (direct effect). They have succesfully examined the direct and indirect effects of trust on a consumer's intention to purchase. The consumer's trust toward the selling party or entity will also increase his intention to purchase indirectly by reducing his or her perceptions of risk (indirect effect) (Kim et, al., 2007).

Perceived Risk and Purchase Intention. Kim et, al., (2007) stated that a consumer's perceived risk is an important barrier for online consumers who are considering whether to make an online purchase and they defined perceived risk as a consumer's belief about the potential uncertain negative outcomes from the online transaction. Since the concept of perceived risk appeared in the marketing literature, various types of risk have been identified (Jacoby and Kaplan, 1972). For example, Jacoby and Kaplan identified seven types of risks: financial, performance, physical, psychological, social, time, and opportunity cost risk. In the case of Web shopping, three types of risk are said to be predominant: financial risk, product risk, and information risk (security and privacy) (Bhatnagar et, al., 2000). A consumer's perceived risk has been found to influence his or her online decisions (Antony et, al., 2006). It is common for a customer who is making an online transaction to be reluctant to purchase on the web because the sense of risk may be overwhelming when compared to the traditional mode of shopping (Kim et, al., 2007).

Perceived Benefit and Purchase Intention. Kim et, al., (2007) define perceived benefit as a consumer's belief about the extent to which he or she will become better off from the online transaction with a certain Website. They revealed that perceived benefit is strong determinant of a consumer's e-commerce transaction decision. Risk is not the only factor consumers are sensitive to in the context of an Internet purchase, the perceived benefit provides consumers with an incentive for purchase behavior (Wilkie and Pessemier, 1973). Combining perceived risk and perceived benefit, Peter and Tarpey, (1975) provided a valence framework which assumes that consumers perceive products as having both positive and negative attributes, and accordingly consumers make decisions to maximize the net valence resulting from the negative and positive attributes of the decision. This framework is consistent with Lewin's theories (1943).

Internet consumers report that they purchase on the Web because they perceive many benefits (e.g., increased convenience, cost savings, time savings, increased variety of products to select from) compared to the traditional mode of shopping (Margherio, 1998). In contrast to perceived risk which provides a potential barrier to the online purchase, an Internet consumer's perceived benefit provides a major incentive for making a purchase online. Consequently, the more consumers perceive benefits related to the online transaction with a certain Website, the more likely they are to make online transactions. The consumer will be more likely to engage in an Internet purchase when perceived benefits are high (Kim et, al., 2007).

Purchase Intention and Purchase Decision. Many e-commerce studies have shown that consumer intentions to engage in online transactions are a significant predictor of consumers' actual participation in e-commerce transactions (Pavlou and Fygenson, 2006). Kim et, al., (2007) also proved that purchase intention is a strong predictor of purchase behavior. They found that these effects of trust, perceived risk, and perceived benefit on purchase intentions, ultimately had a "downstream" effect on consumers' actual purchase decisions. The relationship between intention and behavior is based on the assumption that human beings attempt to make rational decisions based on the information available to them. Thus, a person's behavioral intention to perform (or not to perform) a behavior is the immediate determinant of that person's actual behavior (Ajzen \& Fishbein, 1980). Several results 
showed that when consumers have a higher level of intention to purchase from an Internet vendor's Website, they are more likely to actually purchase from that site.

Based on the above explanations, it was proposed that:

H1: Consumer's trust negatively affects the consumer's perceived risk of a transaction on the internet.

$\mathrm{H} 2$ : Consumer's trust positively affects to purchase intention of the consumers on the internet.

H3: Consumer's perceived risk negatively affects a purchase intention of the consumers on the internet.

H4: Consumer's perceived benefit positively affects a purchase intention of the consumers on the internet.

H5: Purchase intention positively affects the purchase decision on the internet.

Conceptual Framework. Based on the above description of the theory, the developed framework in this study as follows:

Figure 1:- Conceptual Framework

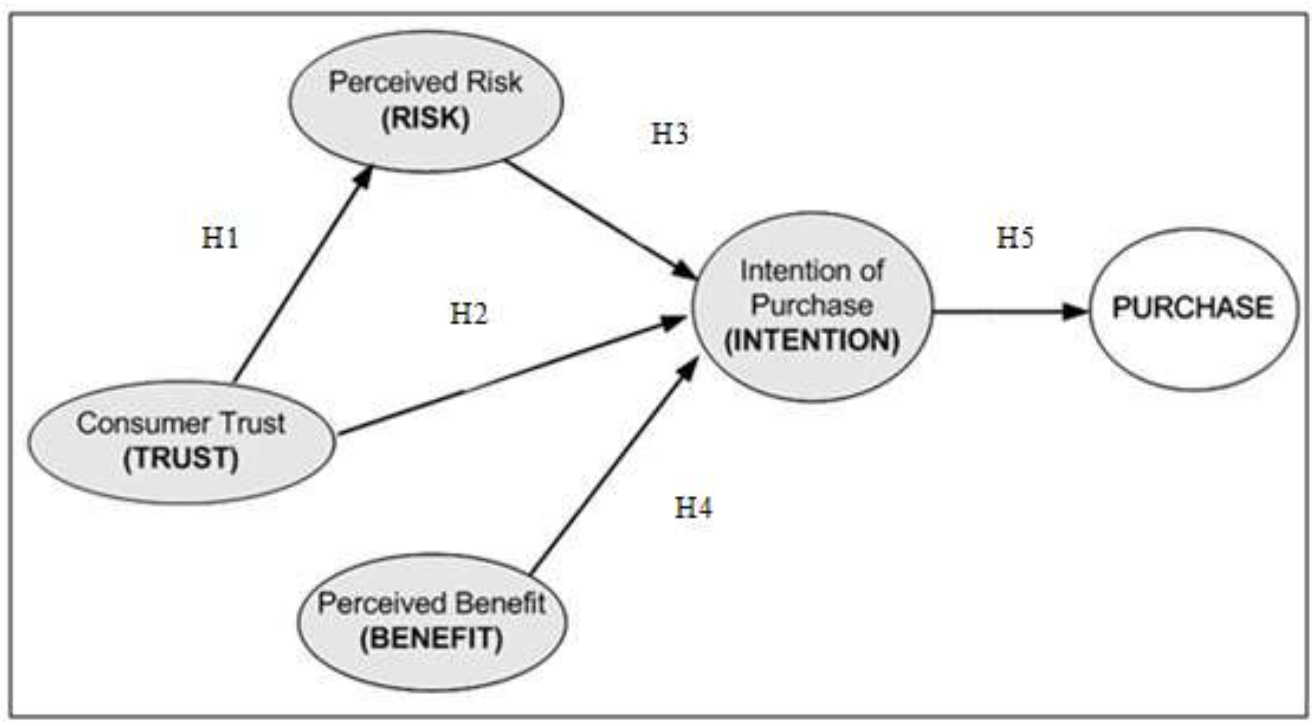

\section{Research Methods:-}

Data collection procedures. The data used in this study is the primary data, ie data collected directly by the researcher to answer the problem or research objectives. Non-probability sampling method with sampling technique, namely Purposive Sampling. Purposive Sampling Technique is a sampling technique in which the sample is selected based on certain considerations or criteria (Sekaran, 2003). The data collected are samples from selected populations based on specific criteria, ie visited B2C sites for the past month. Total samples are 200 respondents. This research uses an observational research design with cross sectional model approach. Data that relates to the independent variable and the dependent variable or the resultant variable, will be collected in the same time (Notoatmodjo, 2007).

Profile of respondents. From the result of data processing related to the characteristics or profile of the respondents, it is found that the majority of respondents were visited B2C sites the past month (100\%), aged 20-30 years (78.5\%), female (69\%), visited Traveloka (14\%), and have bachelor degree (88.5\%).

\section{Research Result And Discussion:}

Evaluation of sample adequacy. To answer the research question about the relationship between variables are used structural equation model (SEM). In this case model testing will use the software assistance, Lisrel. Lisrel is one of the alternative methods of model estimation to manage Structural Equation Modeling (SEM). The sample size plays an important role in estimating and interpreting research results. According to Hair et al., (2010), the results of statistical tests (statistical tests) are very sensitive to the size of the sample size. The exact size of sample size in most scientific studies ranged from 30 to 500 respondents (Sekaran, 2003). Researcher spread the questionnaire as the instrument of this study and took a sample of 200 people to represent the existing population. 
Figure 2:- Validity and Reliability Test Results

\begin{tabular}{|c|c|c|c|}
\hline Indicator & Scale & $\begin{array}{l}\text { Factor } \\
\text { Loading }\end{array}$ & $\begin{array}{l}\text { Cronbach } \\
\text { Alpha }\end{array}$ \\
\hline & Consumer Trust & & 0.779 \\
\hline TRST1 & This site is trustworthy. & 0.67 & \\
\hline TRST2 & $\begin{array}{l}\text { This Website vendor gives the impression that it keeps promises } \\
\text { and commitments. }\end{array}$ & 0.79 & \\
\hline \multirow[t]{2}{*}{ TRST3 } & I believe that this Website vendor has my best interests in mind. & 0.72 & \\
\hline & Perceived Risk & & 0.864 \\
\hline RISK1 & Purchasing from this Website would involve more product risk & 0.75 & \\
\hline RISK2 & Purchasing from this Website would involve more financial risk & 0.88 & \\
\hline \multirow[t]{2}{*}{ RISK3 } & $\begin{array}{l}\text { How would you rate your overall perception of risk from this } \\
\text { site? }\end{array}$ & 0.87 & \\
\hline & Perceived Benefit & & 0.889 \\
\hline BENE1 & I think using this Website is convenient. & 0.68 & \\
\hline BENE2 & I can save money by using this Website. & 0.89 & \\
\hline BENE3 & I can save time by using this Website. & 0.92 & \\
\hline \multirow[t]{2}{*}{ BENE4 } & $\begin{array}{l}\text { Using this Website enables me to accomplish a shopping task } \\
\text { more quickly than using traditional stores }\end{array}$ & 0.91 & \\
\hline & Purchase Intention & & 0.957 \\
\hline INTE1 & I am likely to purchase the products(s) on this site. & 0.90 & \\
\hline INTE2 & I am likely to recommend this site to my friends. & 0.88 & \\
\hline INTE3 & $\begin{array}{l}\text { I am likely to make another purchase from this site if I need the } \\
\text { products that I will buy. }\end{array}$ & 0.95 & \\
\hline
\end{tabular}

Source: Research data, (2017)

Validity and Realibility Result. Cronbach's Alpha at each constructs $>0.70$, this means that all constructs in this study reliable or the answers of the respondents are consistent. In addition, to determine whether the measuring tool is valid or not, the researcher did another way by looking at the value of each factor loading at each indicator. It can be seen in the table above that shows all the measuring tools in this study has a factor loading value $>0.60$.

Evaluation of model conformance. The data in this study were analyzed by using Structural Equation Model (SEM) with Lisrel statistical software. The figure below presents a complete analysis of data using SEM.

Figure 2:- Full Structural Model

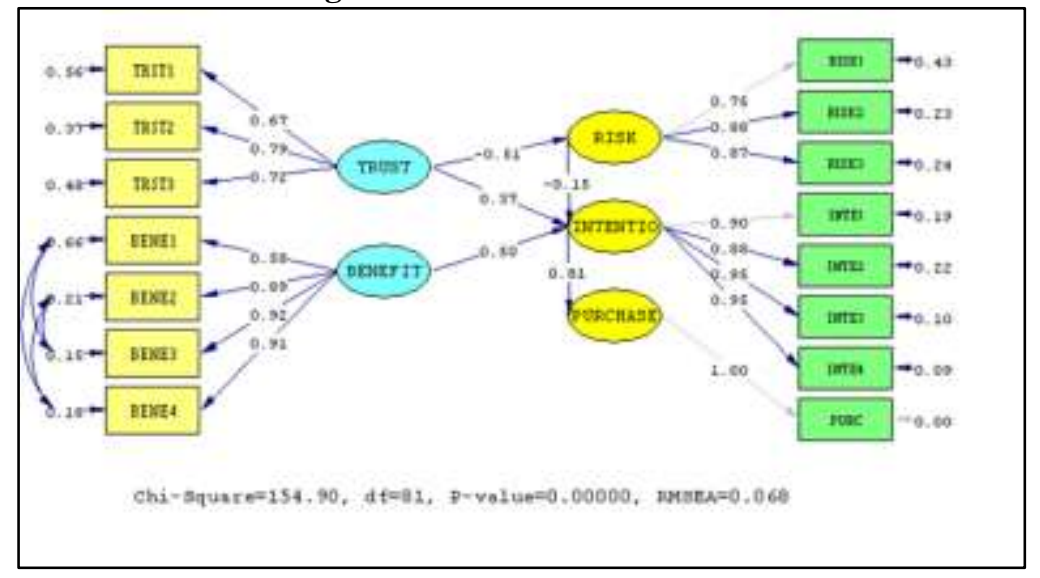

Source: Research data, (2017) 
Results of hypothesis testing. The results of hypothesis testing in this study as follows:

Table 3:- Hypothesis Testing Results

\begin{tabular}{|c|l|c|c|}
\hline \multicolumn{1}{|c|}{ Hypothesis } & T Value & Significance \\
\hline H1 & Consumer Trust -> Perceived Risk & 6.12 & Significance \\
\hline H2 & Consumer Trust -> Purchase Intention & 4.01 & Significance \\
\hline H3 & Perceived Risk -> Purchase Intention & 2.89 & Significance \\
\hline H4 & Perceived Benefit -> Purchase Intention & 5.95 & Significance \\
\hline H5 & Purchase Intention -> Purchase Decision & 15.95 & Significance \\
\hline
\end{tabular}

Source: Research data, (2017)

Table 3 shows that based on data analysis using Lisrel software, there are no rejected hypotheses and all hypotheses are accepted.

\section{Discussion and Conclusion:}

This study fully supports result of the previous research where Kim et al., (2008) have successfully recognized that trust, perceived risk, and perceived benefit may directly influence purchase intentions and decisions, and trust may also influence purchase intentions indirectly by influencing perception of risk. The impact of consumer trust on perceived risk is highly significant at the $\mathrm{T}$ value of $6.12(>1.96)$ with -0.51 of regression weight. Therefore, the result supported hypothesis 1 which predicted that trust has a negative influence on perceived risked. A consumer's trust has a strong positive effect on the purchasing intention as well as a strong negative effect on a consumer's perceived risk (Kim et al., 2008). The result indicates that trust to a large degree addresses the risk problem in ecommerce by reducing perceived risk. Trust is a key determinant of action in a situation in which there is perceived risk of a negative outcome (Luhmann, 1988).

Secondly, the result revealed that there is a positive and significant impact of consumer trust on purchase intention at the $\mathrm{T}$ value of $4.01(>1.96)$ with 0.37 of regression weight. It means that hypothesis 2 which predicted the significant relationship or impact of trust on purchase intention is positively related accepted. Consistent to the research by KIM et. al., (2007 that added trust as critical variable in electronic commerce and also stated that the consumer will be more likely to engage in an internet purchase when trust is high (direct effect). Several trust researchers have shown a direct relationship between trust and willingness to buy online from Internet vendors (Bhattacherjee, 2002; McKnight et, al., 1998).

Hypothesis 3 that predicted the impact of perceived risk on purchase intention is negatively related to purchase intention. This finding supported by the results of significant test at the T value of $2.89(>1.96)$ with -0.15 of regression weight. This is because a customer who is making an online transaction to be reluctant to purchase on the web because the sense of risk may be overwhelming when compared to the traditional mode of shopping (Kim et, al., 2007). When consumers are likely to perceive less risk, then consumers are likely to have an intention to buy a product by using internet.

The relationship between perceived benefit and purchase intention is highly significant at the $\mathrm{T}$ value of 5.95 (>1.96) with 0.50 of regression weight. So that, the significant test result supported hypothesis 4 which predicted that perceived benefit has a positive influence on purchase intention. This results fully supported Margherio, (1998) statement that stated Internet consumers report that they purchase on the Web because they perceive many benefits (e.g., increased convenience, cost savings, time savings, increased variety of products to select from) compared to the traditional mode of shopping.

The significant test reveals that purchase intention and purchase decision are highly significant at the $\mathrm{T}$ value of 15.95 (>1.96) with 0.81 of regression weight. It indicates that purchase intention has a positive impact on purchase decision. This result is supporting Pavlou and Fygenson, (2006) that stated many e-commerce studies have shown that consumer intentions to engage in online transactions are a significant predictor of consumers' actual participation in e-commerce transactions.

Kim et, al., (2007) also proved that purchase intention is a strong predictor of purchase behavior. They found that these effects of trust, perceived risk, and perceived benefit on purchase intentions, ultimately had a "downstream" effect on consumers' actual purchase decisions. 
There are some limitations related to this research. One of the limitations is this study only covered nationwide electronic commerce in Indonesia. Thus, it is suggested that the future research can be done in other developing countries, especially in Southeast Asian (SEA) Countries so that the future researcher will have a new insight in term of behavioral characteristic of SEA consumers in electronic commerce industry. And also higher number of respondents will allow for more robust statistical analyses. Despite its limited sample, the findings from this research can be used to get a better understanding of the characteristics of Internet cyber transactions in electronic industry.

\section{References:}

1. Ajzen, I. Fishbein, M. (1980). Understanding Attitude and Predicting Social Behavior, Prentice-Hall, Inc., Englewood Cliffs, NJ.

2. Asosiasi Penyelenggara Jasa Internet Indonesia (APJII). (2016). Infografis penetrasi pengguna internet Indonesia. Diakses dari http://bit.ly/2jWgb44.

3. Antony, S. Lin, Z. Xu, B. (2006). Determinants of escrow service adoption in consumer-to-consumer online auction market: an experimental study, Decision Support Systems 42 (3) 1889-1900.

4. Balasubramanian, S. Konana, P. Menon, N.M. (2003). Customer satisfaction in virtual environments: a study of online investing, Management Science 49 (7) 871-889.

5. Beatty, S.E. Mayer, M. Coleman, J.E. Reynolds, K.E. J. Lee, (1996). Customer-sales associate retail relationships, Journal of Retailing 72 (3) 223-247.

6. Bhattacherjee, A. (2002). Individual trust in online firms: scale develop-ment and initial test, Journal of Management Information Systems 19 (1) 211-242.

7. Bhatnagar, A. Misra, S. Rao, H.R. (2000). On risk, convenience, and internet shopping behavior, Communications of the ACM 43 (11) 98-114.

8. Blau, P. (1964). Exchange in Power and Social Life, John Wiley, New York, 1964.

9. Canzaroli, A. Tan, Thoen, W. (1999). The Social and Institutional Context of Trust in Electronic Commerce, Presented at Autonomous Agents '99 Workshop "Deception, Fraud and Trust in Agent Societies", 1999, pp. 65-76.

10. Castelfranchi, C. R. Falcone, (1999). The Dynamics of Trust: from Beliefs to Action, Presented at Autonomous Agents '99 Workshop on Deception, Fraud and Trust in Agent Societies, Seattle, WA, 1999, pp. 41-54.

11. Coleman, J. (1990). Foundations of Social Theory, Harvard University Press, Cambridge, Ma.

12. Dailysocial, (2016). Startup Report 2016. Retrieved from: https://dailysocial.id/post/dailysocial-startup-reportindonesia-2016

13. Dasgupta, P. (1990). Trust as a commodity, in: D.G. Gambetta (Ed.),Trust: Making and Breaking Cooperative Relations, Basil Black-well, New York, 1990, pp. 49-72.

14. Dirks, K.T. Ferrin, D.L. (2001). The role of trust in organizational settings, Organization Science 12 (4) 450467.

15. Forrester, US e-business Overview, (2008): 2003-2008, July 25, 2003.

16. Gambetta, D.G. (1988). "Can We Trust Trust?," in Trust: Making and Breaking Cooperative Relations, Gambetta, Ed., electronic edition ed. Department of Sociology, University of Oxford, 213-237.

17. Gefen, D. Straub, D.W. Boudreau, M.C. (2000). Structural equation modeling and regression: guidelines for research practice, Communications of the AIS 4 1-77.

18. Gefen, D. (2002), Reflections on the dimensions of trust and trustworthiness among online consumers, ACM SIGMIS Database 33 (3) (2002) 38-53

19. Grabosky, P. (2001). The nature of trust online, The Age, 2001, pp. 1-12.

20. Gulati, R. (1995). Does familiarity breed trust? The implications of repeated ties for contractual choice in alliances, Academy of Management Journal 38 (1) 85-112.

21. Hair, J.F., Black, W.C., Babin, B.J., Anderson, R.E. (2010): Multivariate Data Analysis, 7th edn. Prentice Hall.

22. Idea, Asosiasi e-commerce Indonesia. "Landskap ecommerce Indonesia 2017".

23. Jacoby, J. Kaplan, L. (1972). The components of perceived risk, Advances in Consumer Research 3. 382-383

24. Jakarta Post, (2017). Retrieved form: http://www.thejakartapost.com/longform/2017/03/03/the-2017indonesian-startup-popular-sector-forecast.html

25. Kim, D.J. Sivasailam, N. Rao, H. R. (2004). Information assurance in B2C websites for information goods/services, Electronic Markets 14 (4) (2004) 344-359.

26. Kim, D.J. Song, Y.I. Braynov, S.B. Rao, H.R. (2005). A multi-dimensional trust formation model in B-to-C ecommerce: a conceptual framework and content analyses of academia/practitioner perspec-tive, Decision Support Systems 40 (2) 143-165. 
27. Kim, D.J. Ferrin, D.L, Rao, H.R. (2007). A trust-based consumer decision-making model in electronic commerce: The role of trust, perceived risk, and their antecedents. Decision Support Systems 44 544-564.

28. Lewin, K. (1943). Forces behind food habits and methods of change, Bulletin of the National Research Council $10835-65$.

29. Luhmann, N. (1988). Familiarity, confidence, trust: problems and alternatives, in: D. Gambetta (Ed.), Trust: Making and Breaking Cooperative Relations, Basil Blackwell, Oxford, pp. 94-107.

30. Margherio, L. (1998). The Emerging Digital Economy, U.S. Department of Commerce, Washington, D.C.

31. Mayer, R.C. Davis, J.H. Schoorman, F.D. (1995). An integrative model of organizational trust, Academy of Management Review 20 (3) 709-734.

32. McKnight, D.H. Chervany, N.L. (2002). What trust means in e-commerce customer relationships: an interdisciplinary conceptual typology, International Journal of Electronic Commerce 6 (2) (2002) 35-60.

33. McKnight, D.H. Choudhury, V. Kacmar, C. (2002). The impact of initial consumer trust on intentions to transact with a web site: a trust building model, Journal of Strategic Information Systems 11 (3-4) 297-323.

34. McKnight, D.H. Cummings, L.L. Chervany, N.L. (1998). Initial trust formation in new organizational relationships, Academy of Management Review 23 (3) 473-490.

35. Notoatmodjo, S. (2007). Pendidikan dan Perilaku kesehatan.Cetakan 2 Jakarta: PT. Rineka Cipta.

36. Pavlou, P.A. Fygenson, M. (2006). "Understanding and Predicting Electronic Commerce Adoption: An Extension of the Theory of Planned Behavior", MIS Quarterly 30 (1) 115-143.

37. Peter, P.J. Tarpey, L.X. (1975). A comparative analysis of three consumer decision strategies, Journal of Consumer Research 2 (1) 29-37.

38. Plank, R.E. Reid, D.A. Pullins, E.B. (1999). Perceived trust in business-to-business sales: a new measure, The Journal of Personal Selling \& Sales Management 19 (3) 61-71.

39. Ratnasingam, P. (1998). The importance of trust in electronic commerce, Internet Research: Electronic Networking Applications and Policy 8 (4) 313-321.

40. Rousseau, D.M. Sitkin, S.B. Burt, R.S. Camerer, C. (1998). Not so different after all: a cross discipline view of trust, The Academy of Management Review 23 (3) 395-404.

41. Sekaran, Uma. (2003). "Research Methods For Business - A Skill Building Approach", Fourth Edition. John Wiley dan Sons, Inc.

42. Startupranking, (2017). Retrieved from: https://www.startupranking.com/top/indonesia

43. Urban, G.L. Sultan, F. Qualls, W.J. (2000). Placing trust at the center of your Internet strategy, Sloan Management Review 42 (1) (2000) 39-48.

44. Whinston, S. Ba, A.B. Zhang, H. (2003). Building trust in online auction markets through an economic incentive mechanism, Decision Support Systems 35 (3) 273-286.

45. Williamson, O.E. (1993). Calculativeness, trust, and economic organiza-tion, Journal of Law and Economics 36 $453-486$.

46. Wilkie, W.L. Pessemier, E.A. (1973). Issues in marketing's use of multi-attribute attitude models, Journal of Marketing Research 10 (4) 428-441. 